\title{
CLIMATE PERIODS IN TREES AND A SEA SEDIMENT CORE
}

LOUIS J PANDOLFI*, EMIL K KALIL**, PAUL R DOOSE**, LAWRENCE H LEVINE*, and LEONA MARSHALL LIBBY***

University of California at Los Angeles, Los Angeles, California 90024

ABSTRACT. Chemical components in a sea sediment core from the Santa Barbara Basin show the same periodic variations as do stable isotope variations in a Japanese cedar.

\section{INTRODUCTION}

Recently, Libby and Pandolfi (1976) reported periodicities found in $\mathrm{O}^{18} / \mathrm{O}^{16}$ and $\mathrm{D} / \mathrm{H}$ ratios measured in a tree-ring sequence of a Japanese cedar spanning about 1800 years. The Fourier transforms of the sequences of isotope ratios versus age into amplitude versus reciprocal period showed ten periods. Some of these periods are evidenced in the Fourier transform of measured variations of carbon-14 content versus age in the bristlecone pine sequence for southern California (Suess, 1970; Libby and Pandolfi, 1976; 1977) measured by Suess (1970).

We report here two additional data sequences (Kalil, ms; Kalil and Kaplan, in press) versus age in which the same periodicities are revealed, namely in the organic carbon and uranium content in an ocean-bottom sediment core taken from the Santa Barbara Basin off the coast of California. Preservation of annual varves in the anoxic sediment provides a record of the past sediments. Fleischer (1972) has described the geography, mineralogy, and sedimentation history of the Santa Barbara Basin.

\section{METHODOLOGY}

The concentrations versus depth of organic carbon, and uranium were measured in sediment samples integrated over approximately sevenyear intervals each in a sea-sediment core spanning the years AD 1264 to 1970 for core number PT-8G from Santa Barbara Basin, collected on the Pleiades Test cruise of the $R V$ Melville of Scripps Institute of Oceanography. The radiocarbon concentration in the bristlecone pine sequence was measured in wood samples integrated over 30 years each in a ring sequence spanning the years AD 100 to 1960. The oxygen and hydrogen isotope ratios in the Japanese tree-ring sequence of cedar were measured in wood samples integrated over about 20 years each for the years AD 100 to 1960 . The ages of the tree rings were determined by tree-ring counting.

The age of sediments versus depth in the sea core was determined by comparison of its varve patterns with varve patterns in core 214 (Doose, ms; Soutar and Isaacs, 1969) and checked with radiocarbon measurements in the calcium carbonate (Kalil and Kaplan, in press). The rate of sedimentation was determined by $\mathrm{Pb}^{210}$ dating (Koide, Soutar, and Goldberg, 1972) in other cores.

\footnotetext{
* Department of Chemistry

** Institute of Geophysics and Planetary Physics Department

*** Energy and Kinetics Department, Environmental Science and Engineering
} 


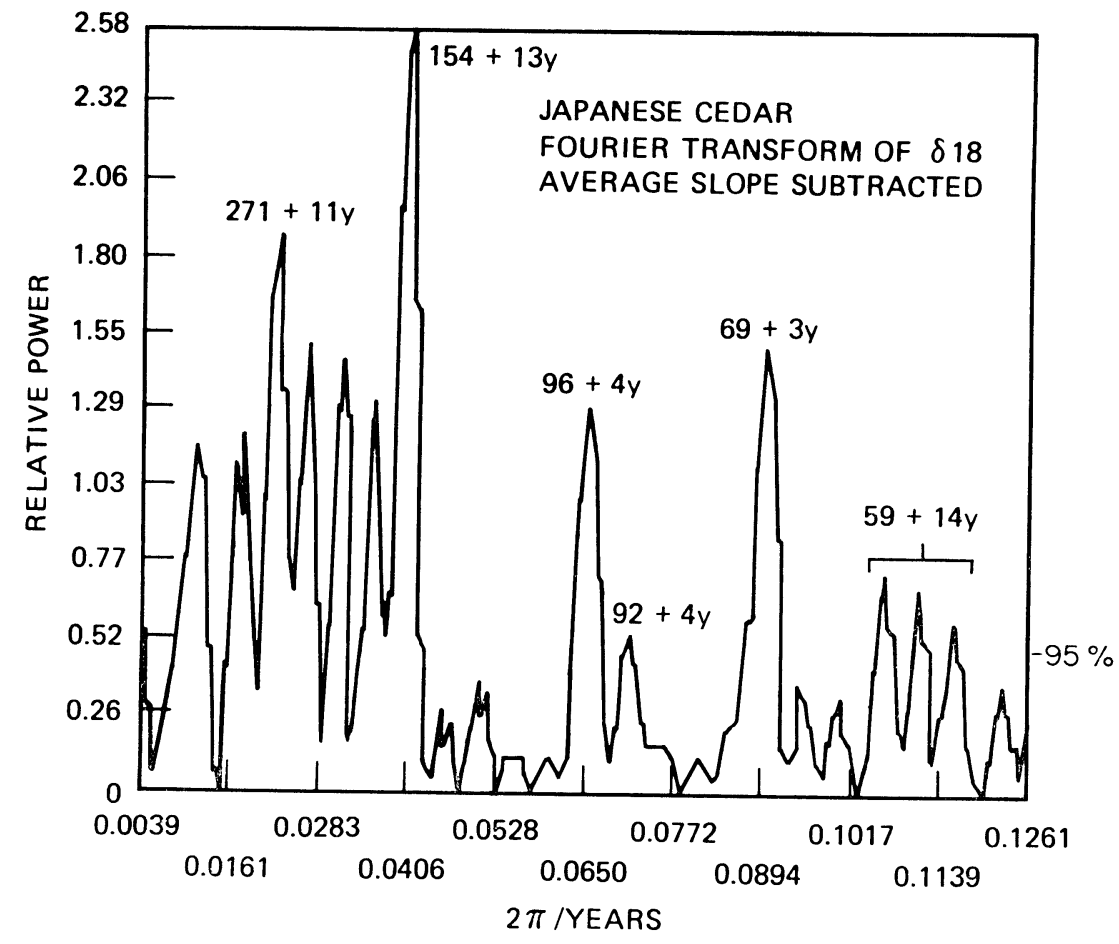

Fig 1. Power spectra for the oxygen isotope ratio in a Japanese cedar.

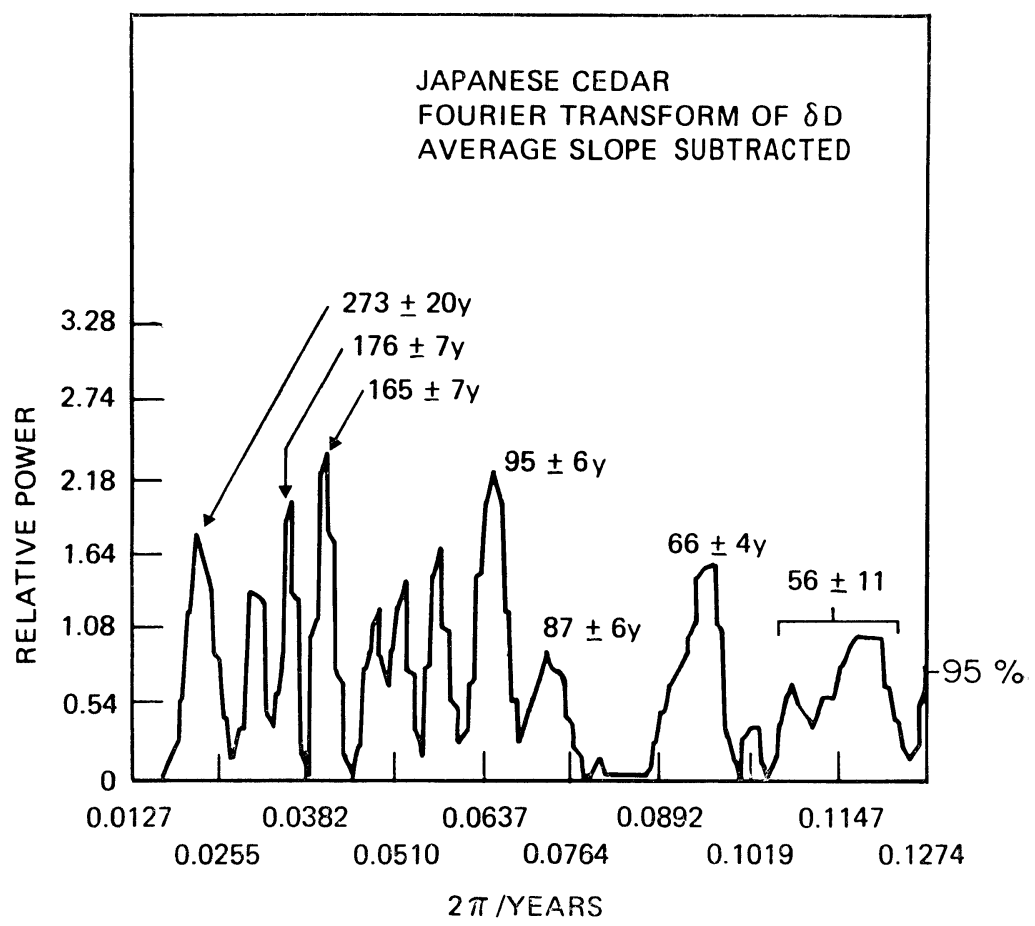

Fig 2. Power spectra for the deuterium isotope ratio in the cedar. 
The age determination allowed Fourier transforms (Blackman and Tukey, 1958; Weast, 1973-74) to be made of each of the data sequences of core components, transforming concentration versus depth in the sediment into signal power and amplitude versus time periodicity. The radiocarbon measurements determine the age versus depth with errors of about \pm 50 years. We make the Fourier transformation in the standard way, but with a modification which removes "red noise" and which, therefore, removes the well-known enhancements at the low frequency end of the power spectrum. Namely, we first make a least squares fit to the plot of measurements versus time and subtract it off before performing the Fourier transform. Thus, of the data fed into the transform, half have positive values and half have negative values.

We have tested data having no "red noise" by manufacturing 100 sets of random numbers with values between the maxima and minima for each of our sets of data, and inputting these random sets through the least squares and the Fourier transform. For each set of measurements, in 100 tests using random data we have found no power peaks reaching

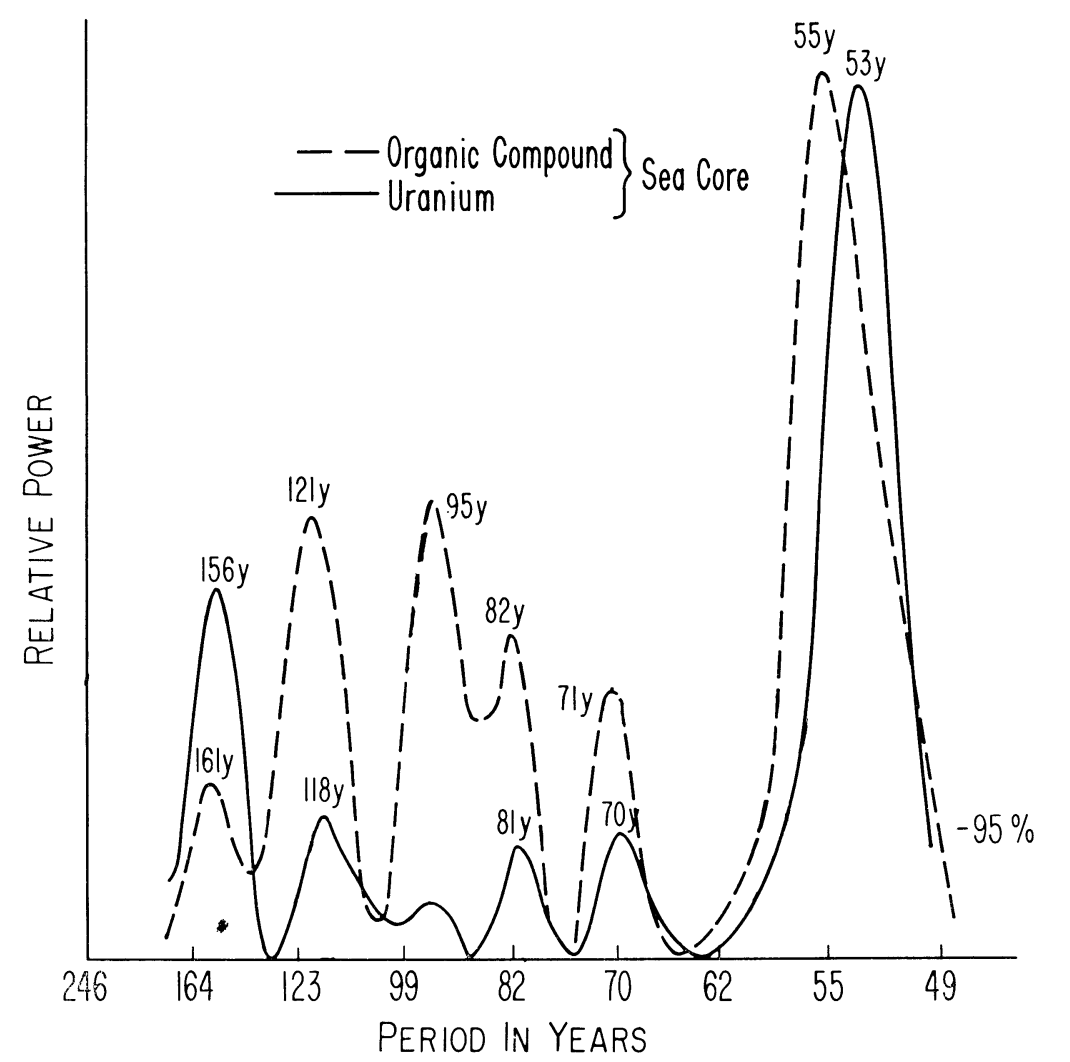

Fig 3. Power spectra for sea core organic carbon concentration and uranium concentration in the sea core. 
the 97 percent confidence level over the entire frequency range. This method of testing, using sets of random data, is commonly used by particle physicists.

It is surprising that the agreements of climate periods in trees (figs 1,2), ice cap, and sea core (fig 3), shown in table 1, exist, considering that the sea-core sediments are subject to the vagaries of winds and currents along the continental shelf of the Santa Barbara Basin and to floods and droughts of California. Agreement is also surprising considering that the trees, the Greenland ice-well, and the sea-sediment core are seemingly unrelated data banks distributed over a wide geographic range from high elevation to below sea level.

\section{CONCLUSION}

Climate variations on a global scale are implied as a cause for the agreements of periodicities found in a Japanese tree, trees from the mountains of southern California, and a sea core from the Santa Barbara Basin (see table 2).

TABle 1

Periodicities, $T$, found in variations of hydrogen and oxygen isotope ratios in a Japanese cedar, in organic carbon and uranium content of a sea core from the bottom of the Santa Barbara channel, and in radiocarbon concentrations in the bristlecone pine ring sequence from the White Mountains of Southern California

Periods yielded from several sets of measurements by Fourier transform (y)

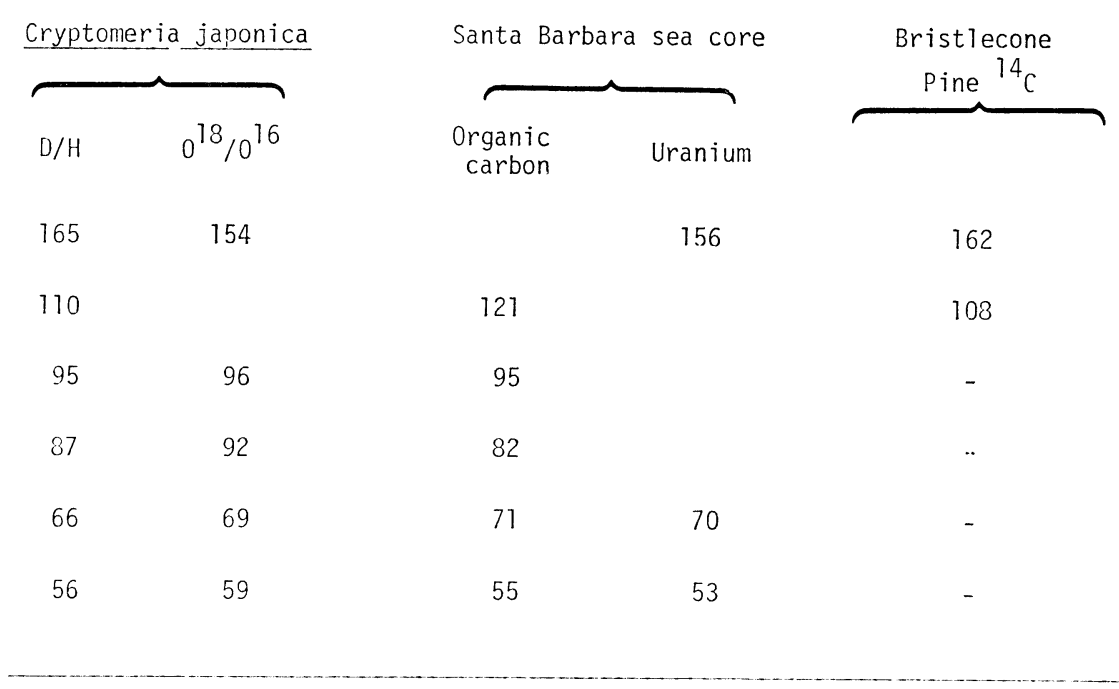


TABle 2

Percent organic carbon and concentration of uranium in ppm versus age of sediment in years for the Santa Barbara sea core

\begin{tabular}{|c|c|c|c|c|c|c|c|}
\hline Years BP & $\begin{array}{l}\text { organic } \\
\text { carbon }\end{array}$ & Years BP & $\begin{array}{c}\text { orcjanic } \\
\text { carbon }\end{array}$ & Years BP & $\begin{array}{l}5 \text { organic } \\
\text { carbon }\end{array}$ & Years BP & $\begin{array}{l}\% \text { organic } \\
\text { carbon }\end{array}$ \\
\hline $\begin{array}{r}0 \\
7 \\
13 \\
20 \\
27 \\
30 \\
40 \\
44 \\
56 \\
60\end{array}$ & $\begin{array}{l}2.60 \\
2.60 \\
1.08 \\
1.27 \\
2.03 \\
3.00 \\
3.00 \\
2.47 \\
3.14 \\
3.14\end{array}$ & $\begin{array}{l}208 \\
216 \\
225 \\
230 \\
236 \\
240 \\
250 \\
258 \\
268 \\
270\end{array}$ & $\begin{array}{l}2.67 \\
3.20 \\
3.33 \\
3.14 \\
2.87 \\
2.74 \\
1.48 \\
2.74 \\
3.74 \\
3.40\end{array}$ & $\begin{array}{l}420 \\
428 \\
438 \\
440 \\
442 \\
448 \\
456 \\
465 \\
470 \\
478\end{array}$ & $\begin{array}{l}3.80 \\
4.42 \\
3.74 \\
3.67 \\
3.33 \\
3.66 \\
3.50 \\
2.41 \\
2.42 \\
2.67\end{array}$ & $\begin{array}{l}620 \\
628 \\
635 \\
640 \\
646 \\
650 \\
660 \\
676 \\
686\end{array}$ & $\begin{array}{l}2.88 \\
2.87 \\
3.07 \\
2.96 \\
2.80 \\
2.94 \\
2.78 \\
2.76 \\
2.87\end{array}$ \\
\hline $\begin{array}{r}74 \\
79 \\
88 \\
94 \\
99 \\
105 \\
112 \\
113 \\
125 \\
136\end{array}$ & $\begin{array}{l}2.80 \\
2.94 \\
2.14 \\
2.60 \\
2.54 \\
2.21 \\
2.42 \\
2.74 \\
3.60 \\
2.87\end{array}$ & $\begin{array}{l}273 \\
280 \\
294 \\
296 \\
304 \\
310 \\
320 \\
325 \\
333 \\
340\end{array}$ & $\begin{array}{l}2.87 \\
2.74 \\
2.14 \\
2.87 \\
2.80 \\
3.20 \\
2.87 \\
3.60 \\
2.78 \\
2.74\end{array}$ & $\begin{array}{l}482 \\
490 \\
496 \\
500 \\
512 \\
522 \\
530 \\
540 \\
548 \\
553\end{array}$ & $\begin{array}{l}2.87 \\
3.00 \\
3.33 \\
2.47 \\
1.63 \\
3.27 \\
2.47 \\
2.47 \\
3.53 \\
3.60\end{array}$ & & \\
\hline $\begin{array}{l}139 \\
148 \\
155 \\
160 \\
170 \\
174 \\
180 \\
188 \\
195 \\
204\end{array}$ & $\begin{array}{l}2.60 \\
3.20 \\
3.27 \\
2.87 \\
3.14 \\
3.00 \\
2.94 \\
2.41 \\
2.54 \\
2.87\end{array}$ & $\begin{array}{l}346 \\
354 \\
360 \\
368 \\
373 \\
378 \\
388 \\
390 \\
403 \\
410\end{array}$ & $\begin{array}{l}3.10 \\
1.41 \\
1.68 \\
2.63 \\
3.43 \\
3.48 \\
3.23 \\
3.43 \\
3.27 \\
3.33\end{array}$ & $\begin{array}{l}560 \\
566 \\
572 \\
576 \\
577 \\
580 \\
590 \\
596 \\
606 \\
615\end{array}$ & $\begin{array}{l}3.67 \\
3.40 \\
2.21 \\
1.93 \\
1.68 \\
3.07 \\
3.27 \\
3.00 \\
2.74 \\
2.70\end{array}$ & & \\
\hline rears $B P$ & $\begin{array}{c}\text { ppri } \\
\text { uranium }\end{array}$ & Years BP & $\begin{array}{c}\text { ppil } \\
\text { uraniun }\end{array}$ & Years BP & $\begin{array}{c}\text { ppm } \\
\text { uranium }\end{array}$ & Years BP & $\begin{array}{c}\mathrm{ppm} \\
\text { uranium } \\
\end{array}$ \\
\hline $\begin{array}{r}0 \\
4 \\
12 \\
14 \\
25 \\
30 \\
39 \\
43 \\
57 \\
67\end{array}$ & $\begin{array}{l}4.87 \\
5.08 \\
4.92 \\
5.35 \\
4.87 \\
4.92 \\
3.94 \\
4.99 \\
5.50 \\
5.32\end{array}$ & $\begin{array}{l}203 \\
210 \\
220 \\
225 \\
234 \\
239 \\
250 \\
255 \\
258 \\
272\end{array}$ & $\begin{array}{l}5.02 \\
5.60 \\
5.72 \\
5.20 \\
5.20 \\
5.14 \\
4.04 \\
4.92 \\
5.25 \\
6.18\end{array}$ & $\begin{array}{l}414 \\
418 \\
425 \\
423 \\
439 \\
440 \\
445 \\
452 \\
460 \\
470\end{array}$ & $\begin{array}{l}5.14 \\
5.40 \\
5.45 \\
5.97 \\
5.55 \\
5.14 \\
5.35 \\
5.45 \\
4.20 \\
4.50\end{array}$ & $\begin{array}{l}615 \\
620 \\
629 \\
633 \\
637 \\
641 \\
646 \\
651 \\
660 \\
673\end{array}$ & $\begin{array}{l}4.50 \\
4.25 \\
4.35 \\
4.52 \\
5.08 \\
4.25 \\
4.30 \\
4.30 \\
4.56 \\
4.09\end{array}$ \\
\hline $\begin{array}{r}71 \\
80 \\
87 \\
94 \\
99 \\
107 \\
112 \\
118 \\
126 \\
135\end{array}$ & $\begin{array}{l}4.87 \\
5.40 \\
4.82 \\
5.55 \\
5.37 \\
4.66 \\
4.65 \\
5.45 \\
5.18 \\
5.82\end{array}$ & $\begin{array}{l}276 \\
280 \\
290 \\
296 \\
306 \\
310 \\
317 \\
320 \\
333 \\
340\end{array}$ & $\begin{array}{l}5.66 \\
5.02 \\
4.25 \\
5.35 \\
5.25 \\
5.25 \\
5.16 \\
5.35 \\
6.13 \\
6.12\end{array}$ & $\begin{array}{l}475 \\
482 \\
490 \\
493 \\
500 \\
507 \\
510 \\
518 \\
525 \\
536\end{array}$ & $\begin{array}{l}4.72 \\
4.82 \\
5.08 \\
5.25 \\
4.40 \\
3.94 \\
4.20 \\
4.97 \\
5.16 \\
5.30\end{array}$ & & \\
\hline $\begin{array}{l}140 \\
145 \\
155 \\
162 \\
170 \\
174 \\
179 \\
132 \\
192 \\
193\end{array}$ & $\begin{array}{l}5.02 \\
5.02 \\
4.61 \\
4.88 \\
5.08 \\
5.08 \\
5.03 \\
4.40 \\
4.45 \\
5.50\end{array}$ & $\begin{array}{l}345 \\
350 \\
360 \\
365 \\
372 \\
380 \\
386 \\
388 \\
390 \\
396\end{array}$ & $\begin{array}{l}5.66 \\
4.75 \\
4.61 \\
5.50 \\
6.13 \\
6.18 \\
5.97 \\
4.82 \\
5.14 \\
5.25\end{array}$ & $\begin{array}{l}545 \\
550 \\
555 \\
559 \\
570 \\
575 \\
580 \\
595 \\
600 \\
605\end{array}$ & $\begin{array}{l}5.50 \\
5.25 \\
5.77 \\
5.50 \\
4.77 \\
4.30 \\
5.02 \\
5.20 \\
4.77 \\
4.48\end{array}$ & & \\
\hline
\end{tabular}


REFERENCES

Blackman, R B, and Tukey, J W, 1958, The measurement of power spectra: New York, Dover, p 7-9.

Doose, P R, ms, 1978, Geochemistry of a Santa Barbara sea core: PhD thesis, Univ California at Los Angeles.

Fleischer, P, 1972, Mineralogy and sedimentation history: Santa Barbara Basin: Jour Scdimentary Petrology, v 42, p 49-58.

Kalil, E K, ms, 1976, Distribution and geochemistry of uranium in recent and Pleistocene marine sediments: PhD thesis, Univ California at Los Angeles.

Kalil, E $\mathbf{K}$ and Kaplan, I R, in press, Uranium distribution in marine sediments: Marine Chemistry, in press.

Koide, Minoru, Soutar, Andrew, and Goldberg, E D, 1972, Marine geochronology with lead - 210: Earth Planetary Sci Letters, v 14, p 442-446.

Libby, L $M$ and Pandolfi, L J, 1976, Isotope tree thermometers; correlation with radiocarbon: Jour Geol Research, v 81, p 6377-6381.

Libby, L M and Pandolfi, L J, 1977, Climate periods in tree, ice, and tides: Nature, v 266, p 415-417.

Libby, L M, Pandolfi, L J, Payton, P H, Marshall, John, III, Becker, Bernd, and Giertz-Sievenlist, V, 1976, Isotopic tree thermometers: Nature, v 261, p 284-288.

Soutar, Andrew and Isaacs, J D, 1969, Sea core chronology in Santa Barbara Basin: State of California Marine Research Committee, California Cooperative Oceanic Fisheries Investigation, v 13, p 63-70.

Suess, H E, 1970, Bristlecone pine calibration of the radiocarbon time scale $5200 \mathrm{BC}$ to the present, in Olsson, I $\mathrm{U}$, ed, Radiocarbon variations and absolute chronology: New York, John Wiley \& Sons, p 303-311.

Weast, R C, ed, 1973-74, Handbook of chemistry and physics, 54th ed: Cleveland, Ohio, Chem Rubber Co, p A-170-171. 